\title{
KONSTRIBUSI PONDOK PESANTREN DALAM MENANAMKAN KARAKTER WASHATIYAH DI YAYASAN PONDOK PESANTREN QAMARUL HUDA BAGU (YP2QH)
}

\author{
Badrun \\ Universitas Islam Negeri Mataram \\ badrunmuslim1962@gmail.com
}

\begin{abstract}
Islamic boarding schools basically have a distinctive soul and philosophy. This spirit and philosophy guarantees the existence of the pesantren, and even becomes the driving force in educating students and maintaining the continuity of the institution towards progress in the future. The pesantren has five souls or it can be called five souls, namely sincerity, simplicity, independence, ukbuwah / brotherhood, and freedom in determining the field of struggle. As an educational institution, Islamic boarding schools have a big role as a fortress to defend the nation's moral values. However, the decline in moral and etbical values will affect the integrity of the nation and state. Therefore, the government has determined character education as a content that must be present at every level of education, including in Islamic boarding schools.
\end{abstract}

Keywords: Islamic Boarding School, Washatiyah Character

\begin{abstract}
Abstrak : Pondok pesantren pada dasarnya memiliki jiwa dan falsafah yang khas. Jiwa dan falsafah tersebut menjamin eksistensi pesantren, bahkan menjadi motor penggerak dalam mendidik santri dan mempertahankan kelangsungan lembaga menuju kemajuan di masa datang. Pesantren mempunyai lima jiwa atau bisa disebut dengan Panca Jiwa, yaitu keikhlasan, kesederhanaan, kemandirian, ukhuwah/persaudaraan, dan kebebasan dalam menentukan lapangan perjuangan. Sebagai lembaga pendidikan, pondok pesantren memiliki peran yang besar sebagai benteng untuk mempertahankan nilai-nilai moral bangsa. Namun demikian, kemerosotan nilai moral dan etika akan berpengaruh terhadap integritas berbangsa dan bernegara. Oleh karena itu, pemerintah telah menetapkan pendidikan karakter sebagai muatan yang harus ada dalam setiap jenjang pendidikan, termasuk di pondok pesantren.
\end{abstract}

Kata Kunci : Pondok Pesantren, Karakter Washatiyah

\section{PENDAHULUAN}

Keberadaan pondok pesantren sering dipahami secara keliru oleh banyak orang, atau sering ditafsirkan sebagai "dunia tertutup." Sesungguhnya, pondok pesantren telah berperan penting dalam memproduksi kader-kader dalam jumlah besar yang akhirnya tampil sebagai lokomotif "keterbukaan" dalam perjuangan bangsa Indonesia, sejak zaman penjajahan sampai dewasa ini. Dalam hal ini, pondok pesantren merupakan 
institusi sosial yang melakukan transformasi nilai-nilai transenden dan imanen yang menjadi karakteristik masyarakat Indonesia. Sementara itu, fungsi utama pondok pesantren adalah: (a) menyiapkan santri mendalami dan menguasai ilmu agama Islam (tafaqquh fi al-din) yang diharapkan dapat mencetak ulama dan turut mencerdaskan masyarakat Indonesia, (b) dakwah menyebarkan Islam, dan (c) benteng pertahanan umat dalam akhlak. ${ }^{1}$

Sistem pendidikan yang dikembangkan di pondok pesantren dicirikan oleh beberapa hal: (a) memakai sistem tradisional yang memiliki kebebasan penuh dibandingkan dengan sekolah modern, sehingga terjadi hubungan dua arah antara kiai dan santri, (b) kehidupan di pesantren menampakkan semangat demokrasi karena para santri praktis bekerjasama mengatasi problem non-kurikuler mereka sendiri, (c) para santri tidak mengidap penyakit simbolis, yaitu perolehan gelar dan ijazah karena sebagaian besar pesantren tidak mengeluarkan ijazah, (d) sistem pesantren mengutamakan kesederhanaan, idealisme, persaudaraan, persamaan, rasa percaya diri dan keberanian hidup, dan (e) alumni pondok pesantren tidak bercita-cita menduduki jabatan pemerintah, sehingga mereka tidak dapat dikuasai oleh pemerintah. ${ }^{2}$

Pesantren memiliki falsafah yang menjadi mutiara hikmah bagi seluruh warga pesantren. Pesantren adalah lapangan perjuangan, bukan lapangan penghidupan, sehingga warga peesantren harus menghidupkan pesantren, dan tidak menggantungkan hidup kepada pesantren Pesantren adalah tempat ibadah dan thalabul ílmi. Sedangkan beberapa falsafah pendidikan yang ditanamkan kepada para santri bahwa: apa yang dilihat, didengar, dirasakan dan dikerjakan oleh santri sehari-hari mengandung nilai pendidikan: hidup sekali, hiduplah yang berarti, berani hidup tak takut mati, takut mati, jangan hidup, kalau takut hidup lebih baik mati saja; berjasalah, tetapi jangan minta jasa; sebaik-baik manusia adalah yang paling bermanfaat bagi sesamanya; hanya orang penting yang tahu kepentingan, dan hanya pejuang yang tahu arti perjuangan. Falsafah pendidikan tersebut diperkuat dengan falsafah pembelajaran di pesantren, yakni: metode lebih penting dari pada materi, guru lebih penting daripada metode, jiwa guru lebih

\footnotetext{
${ }^{1}$ Departemen Agama RI, Direktorat Jenderal Kelembagaan Agama Islam, Direktorat Pendidikan Keagamaan dan Pondok Pesantren Proyek Peningkatan Pondok Pesantren, Profil Pondok Pesantren Mu'adalah (Jakarta: Direktorat Pendidikan Keagamaan dan Pondok Pesantren Departemen Agama, 2004), hlm. 3.

${ }^{2}$ Ibid.
} 
penting dari pada guru itu sendiri; pesantren memberikan kail, tidak memberi ikan, ujian untuk belajar, bukan belajar untuk ujian; ilmu bukan untuk ilmu, tetapi ilmu untuk amal dan ibadah. ${ }^{3}$

Pondok Pesantren Qamarul Huda Bagu adalah salah satu pondok pesantren di Pulau Lombok yang tidak hanya mengelola pendidikan agama, tetapi juga pendidikan umum. Kepemimpinan pada Yayasan Pondok Pesantren Qamarul Huda Bagu masih berrada di tangan pendiri pondok pesantren, yaitu TGH. Lalu Moh. Turmudzi Badaruddin. Pendirian pondok pesantren ini dilatarbelakangi oleh keprihatinan pada kehidupan masyarakat yang sangat miskin, sehingga tidak dapat menyekolahkan anakanak mereka ke tempat lain di luar Bagu. Selain itu, Tuan Guru merasa memiliki kewajiban untuk menyebarkan ajaran Islam yang benar yang bersumber dari Alquran dan hadis.

Pondok Pesantren Qamarul Huda Bagu dikenal sebagai basis pengembangan nilainilai Islam yang bersifat esensial yang mendasari pendidikan karakter. Proses tersebut tidak bisa dipisahkan dari peran sentral tuan guru. Beberapa studi menunjukkan bahwa sampai dewasa ini kiai pesantren merupakan seorang pemimpin yang kharismatik. Kharisma yang dimiliki kiai merupakan salah satu kekuatan yang dapat menciptakan pengaruh dalam lingkungannya. Kiai tidak memandang komponen pesantren lainnya, seperti pengurus, santri dan masyarakat, sebagai bawahannya, tetapi sebagai partner kerja. $^{4}$

Unsur-unsur nilai karakter yang dikembangkan di Pondok Pesantren Qamarul Huda Bagu bersumber dari Alquran dan hadis serta nilai luhur yang bersumber dari budaya bangsa. Penanaman unsur-unsur nilai karakter tersebut, khususnya kemandirian dan kedisplinan, dilaksanakan dengan pendekatan menyeluruh melalui pembelajaran, pembiasaan, ekstra-kurikuler dan kerjasama dengan orang tua dan masyarakat. Di samping itu, pendidikan karakter dilakukan dengan menggunakan metode nasehat, pembiasaan, pahala, dan sanksi serta keteladanan dari kiai dan pengajarnya.

3 M Zainul Fadli dan Erna Sulistyowati, "Peran Pesantren Mahasiswa dalam Membentuk Karakter Dokter Muslim," Jurnal Kesehatan Islam, Volume 1, 1 (2013), hlm. 1-12.

4 A. Mubsiroh, Nengah Bawa Atmaja, Nyoman Natajaya, "Manajemen Pondok Pesantren Tahfidz Qur'an Raudlotul Huffadz Tabanan Bali (Kepemimpinan, Cara Belajar)," Jurnal Penelitian Pasca Sarjana Undiksa, Vol. 4, 1 (2013), hlm. 1-10. 
Dalam praktik, pembinaan karakter mandiri dan disiplin santri mengalami beberapa kendala, baik yang bersifat internal maupun eksternal. Namun, beberapa kendala tersebut masih dapat ditangani oleh pengelola Pondok Pesantren Qamarul Huda Bagu. Keunggulan hasil yang dikembangkan dalam membangun kemandirian dan kedisiplinan santri pada pondok pesantren dibuktikan dengan: (1) adanya perubahan yang semakin baik dalam sikap, tata krama dan prilaku santri; (2) munculnya kemandirian santri dalam berpikir dan bertindak; (3) munculnya kedisiplinan santri dalam mengelola waktu dan mentaati tata peraturan; dan (4) munculnya figur-figur yang menjadi panutan dalam lingkungan masyarakat, baik dalam bidang agama mapun umum. ${ }^{5}$

\section{PENANAMAN PENDIDIKAN KARAKTER DI PONDOK PESANTREN QAMARUL HUDA BAGU}

Pendidikan karakter adalah proses penanaman nilai-nilai karakter pada peserta didik, yang mengandung komponen pengetahuan, kesadaran individu, tekad, kemauan dan tindakan untuk melaksanakan nilai-nilai, terhadap Tuhan Yang Maha Esa dan sesama manusia. ${ }^{6}$ Dalam hal ini, makna pendidikan karakter dapat dijelaskan sebagai berikut:

Pendidikan karakter jika dilihat dalam konteks pendidikan formal adalah mendidik peserta didik membiasakan hal agar tertanam dalam dirinya sifat dan prilaku yang baik dan berusaha menyadarkan peserta didik yang memiliki sifat dan prilaku buruk. Makna lain menekankan pengertian pendidikan karakter dalam konteks rumah tangga (pendidikan informal), bahwa pendidikan karakter tabiat, sifat, watak, dan kepribadian seseorang dilakukan dengan cara menanamkan nilai-nilai luhur, sehingga nilai-nili luhur mendarah daging, menyatu dalam hati, dan menampakkan pengaruh dalam kehidupannya secara sadar. Dalam hal ini, pendidikan karakter suatu kegiatan sekolah untuk membentuk prilaku siswa secara sistimatis. Oleh karena itu, pengertian pendidikan karakter harus dibedakan dalam konteks pendidikan karakter dalam lingkungan pendidikan formal maupun informal; pendidikan karakter di sekolah hanya mampu mewujudkan kebiasaan baik di rumah dan menyadarkan peserta didik yang memiliki kebiasaan buruk di rumah. ${ }^{7}$

\footnotetext{
${ }^{5}$ Ibid.

${ }^{6}$ Nuria Isna Aunnilah, Panduan Menerapkan Pendidikan Karakter di Sekolah (Laksana, 2011), hlm. 18.

${ }^{7}$ Syukri, Esensi Pendidikan Karakter dalam Perspektif Islam (Mataram: IAIN Mataram, 2013), hlm. 195-197.
} 
Selain itu, pendidikan karakter sering disamakan dengan pendidikan moral, atau karakter versus moral dan etika versus akhlak. Namun, pendidikan karakter bukan sekedar mengajarkan mana yang benar dan mana yang salah, sebagaimana pendidikan moral cenderung pada nilai yang baik dan buruk. Demikian pula dengan etika yang bertitik tolak dari akal pikiran, bukan dari agama. Di sinilah letak perbedaan antara etika dan akhlak. ${ }^{8}$

Dimensi karakter yang berkaitan dengan dimensi etika dan akhlak dapat dibedakan sebagai berikut: (1) etika Islam menetapkan bahwa sumber moral dan ukuran baikburuknya perbuatan adalah Alquran dan Sunnah, (2) etika Islam bersifat universal dan komprehensif dapat diterima oleh seluruh manusia di segala waktu dan tempat, (3) etika Islam mengatur dan mengarahkan fitrah manusia ke jenjang akhlak yang luhur dan meluruskan perbuatan manusia. ${ }^{9}$

Ruang lingkup karakter atau kepribadian merupakan kumpulan jenis-jenis nilai yang dapat diwujudkan dalam konsep dan sikap pada kehidupan manusia. Jenis-jenis nilai karakter tersebut dari perspektif Islam dapat dirumuskan dalam empat komponen utama dari sifat Nabi Muhammad, yaitu shidq, amanah, tabligh dan fathanah. ${ }^{10}$ Deskripsi tentang konsep pada masing-masing komponen utama tersebut dijelaskan pada Gambar:

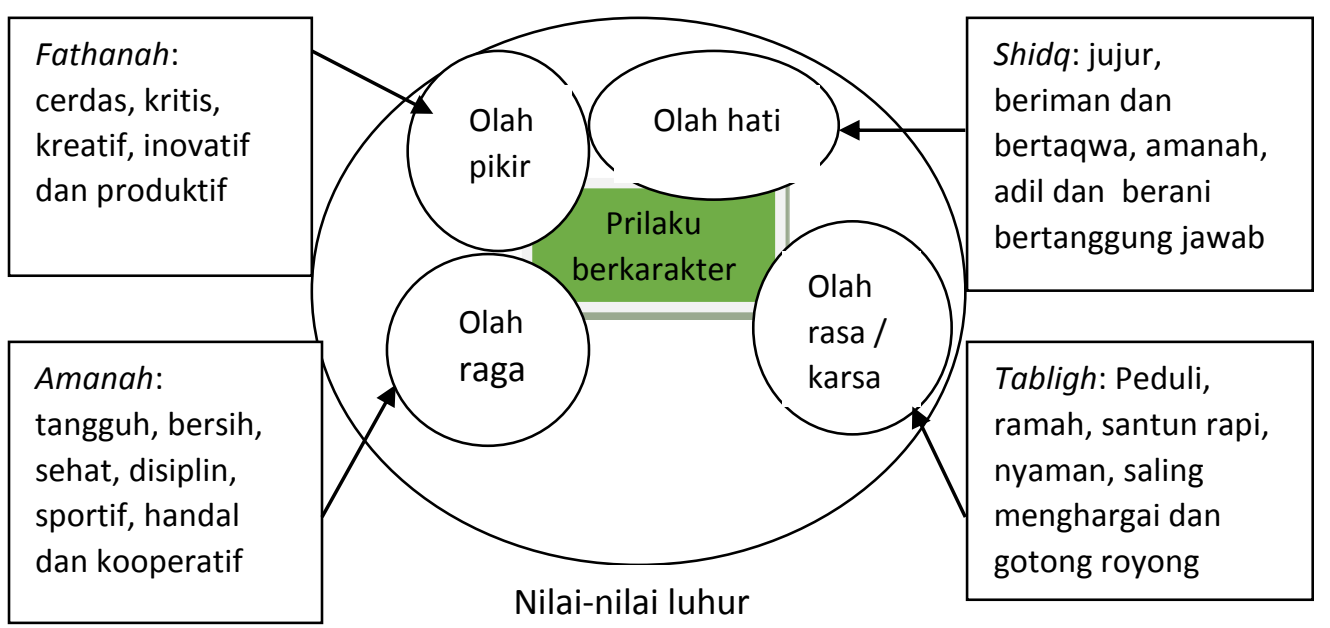

Gambar 1. Karakter Esensial dalam Islam

\footnotetext{
${ }^{8}$ Dian Andayani dan Abdul Majid, Pendidikan Karakter Perspektif Islam (Bandung: Remaja Rosda Karya, 2011), hlm. 14-15.

${ }^{9}$ Ibid., hlm. 15.

${ }^{10}$ Ibid., hlm. 24-25.
} 
Pondok Pesantren Qamarul Huda Bagu mempunyai banyak tanggung jawab, baik bersifat ilmiah, washatiyah maupun bashariyah, namun secara garis besarnya memiliki dua tanggung jawab dalam mendidik santrinya, yaitu tanggung jawab secara vertikal dan horizontal. Tanggung jawab vertikal tersebut tentu berhubungan dengan tanggung jawab kepada Allah, sedangkan tanggung jawab horizontal berhubungan dengan strategi dan teknik mempersiapkan santri untuk menjadi anggota masyarakat yang mandiri dan bermanfaat bagi lingkungan. Berkaitan dengan tanggung jawab intelektual tersirat peran pondok pesantren, di antaranya: (a) pondok pesantren sebagai wadah dakwah Islamiah dan pengembangan masyarakat, dan (b) pondok pesantren memiliki tanggung jawab yang cukup besar mempersiapkan santrinya dengan kapasitas intelektual yang memadai baik secara vertikal dan horizontal. ${ }^{11}$ Peran pondok pesantren dapat dilihat dari tujuan orang untuk memperoleh pendidikan di pondok pesantren, yaitu: (a) resepsi sekaligus kontinuasi dan ortodoksi geneo-sosio-religius mereka, agar tidak diklaim sebagai "agama salah kaprah", dan (b) pondok pesantren sebagai tempat kaderisasi kaum moralis. ${ }^{12}$

Konsep nilai pendidikan karakter yang dikembangkan adalah konsep nilai karakter yang diperoleh dari sumber nilai karakter, yaitu Alquran, hadis dan kitab para ulama. Dalam mengembangkan pendidikan karakter, YP2QH Bagu tidak keluar dari kerangka nilai-nilai yang ada dalam sumber-sumber tersebut. TGH. Lalu. Moh. Turmudzi Badaruddin mengemukakan:

Jenis-jenis nilai pendidikan karakter (akhlak) yang sudah tersurat secara jelas dalam Alquran dan Hadist serta terungkap secara jelas dalam kitab serta pendapat para ulama terkenal adalah merupakan jenis nilai pendidikan karakter yang dikembangkan pada YP2QH Bagu. TGH. Lalu. Moh. Turmudzi Badaruddin menyatkan nilai-nilai karakter yang ada dalam sumber nilai yang menjadi rujukan yang telah disebutkan di atas sudah cukup lengkap sebagai dasar pengembangan pendidikan karakter. Misalnya nilai karakter tentang jujur, adil, tanggung jawab, kasih sayang, bekerjasama dan ikhlas dan jenis nilai yang lain sudah cukup jelas. Selanjutnya disebutkan dalam keseharian yang paling penting dalam pengembangan pendidikan karakter tentang —adab. Nilai karakter ini memiliki makna yang cukup penting dalam membentuk karakter khususnya pada para santri yang sedang belajar. ${ }^{13}$

\footnotetext{
${ }^{11}$ Faiqoh, Prospek dan Problem Pesanteren di Era Modern (Gaung Persada Press, 2013), hlm. 146.

12 M. Tholhah Hasan, Intelektualisme Pesantren: Potret Tokob dan Cakrawala Pemikiran di Era Perkembangan Pesantren (Diva Pustaka, 2004), hlm. 1-7.

${ }^{13}$ Wawancara dengan TGH. Lalu. Moh. Turmudzi Badaruddin, 1-7 Agustus 2019.
} 
Sebagai lembaga pendidikan Islam, YP2QH Bagu mengembangkan nilai-nilai karakter dengan ciri-ciri: (1) memiliki ilmu yang tinggi, (2) suka beramal, (3) taqwa, (4) berakhlaqul karimah, (5) berbudaya, (6) bermoral, dan (7) memiliki tanggung jawab terhadap masa depan bangsa dan negara Indonesia. Hal sesuai dengan tujuan pendidikan karakter dalam konteks kebangsaan yang diarahkan untuk memiliki karakter sesuai dengan nilai-nilai dasar _Pancasilall. Uraian tentang jenis-jenis nilai karakter tersebut memberikan pemahaman tentang keutamaan jenis-jenis nilai karakter yang dikembangkan pada YP2QH Bagu. TGH. Lalu. Moh. Turmudzi Badaruddin menyatakan sebagai berikut:

Jenis-jenis nilai karakter untuk dikembangkan adalah: (1) jenis-jenis nilai karakter merupakan sumber nilai yang menjadi jiwa santri dalam kehidupan sehari-hari, (2) santri generasi penerus dalam menyebar-luaskan nilai-nilai akhlak mulia kepada masyarakat, (3) santri adalah potret pondok pesantren ditengahtengah masyarakat dan (4) santri adalah orang yang dituakan dalam agama oleh masyarakat. $^{14}$

Data di atas memberikan informasi bahwa Tuan Guru YP2QH Bagu memiliki dasar konseptual yang sangat sahih dalam pengembangan pendidikan karakter. Selain itu, Tuan Guru memiliki keyakinan yang sangat tinggi bahwa melalui pengembangan jenisjenis nilai karakter, visi, misi dan tujuan pendirian pondok pesantren dapat dicapai. Oleh karena itu, pengembangan pendidikan karakter tidak boleh dilepaskan dari sumber dasar jenis-jenis nilai karakter, yaitu Alquran dan hadis.

Pendidikan karakter pada pondok pesantren YP2QH Bagu adalah bagian integral dari tujuan penyelenggaraan pendidikan. Nilai karakter yang terakumulasi sebagai akhlak mulia dapat dioperasionalkan dalam bentuk indikator. Berkaitan dengan indikator pengembangan pendidikan karakter, TGH. Lalu. Moh. Turmudzi Badaruddin mengatakan:

Indikator dalam pengembangan pendidikan karakter pada YP2QH Bagu dapat dilihat dari hasil pendidikan pada para santri. Hasil konkrit yang dapat dilihat sebagai bentuk dari pengembangan pendidikan karakter adalah: (1) sopan santun para santri dalam berpakaian dan berbicara, (2) kedisplinan, (3) ketekunan dalam belajar, (4) pemanfaatan waktu, (5) kepedulian pada sesama santri, (6) sabar dan ikhlas serta istikomah dengan kondisi apa adanya pada pondok pesantren dan (7) taat beribadah pada Allah baik itu ibadah wajib dan sunnah.

\footnotetext{
${ }^{14}$ Wawancara dengan TGH. Lalu. Moh. Turmudzi Badaruddin, 1-7 Agustus 2019.
} 
Indikator yang disebutkan di atas adalah indikator dalam keseharian para santri pada YP2QH Bagu. Indikator lain yang cukup penting terkait dengan pengembangan pendidikan karakter adalah indikator formal. Peneliti melakukan wawancara dengan kepala madrasah, yaitu: (1) H. Mahyudin Spd. MPd.I, Kepala MTs, (2) H. Zarkasi Ependi Spdi. MPd.I, Kepala MA, (3) H. Lalu Barsya, Kepala MI, (4) H. Muh. Tamin Lc (guru dan pengasuh pondok), dan (5) H. Moh. Yunus SPd.I, (guru dan pengasuh pondok). Mereka mengungkapkan pandangan yang dapat dirangkum sebagai berikut:

Jenis-jenis nilai pendidikan akhlak (karakter) yang dikembangkan pada pondok pesantren YP2QH Bagu tidak berbeda dari yang telah diungkapkan oleh TGH. Lalu. Moh. Turmudzi Badaruddin. Namun demikian, indikator yang dapat ditunjukkan dalam implementasi pengembangan pendidikan karakter pada tiap satuan pendidikan ada dalam kurikulum. Indikator dari hasil pengembangan pendidikan karakter dapat dilihat pada nilai rapot yang diperoleh oleh semua peserta didik pada tiap satuan pendidikan, khususnya pada mata pelajaran-mata peljaran yang memiliki relevansi tinggi dengan pengembangan pendidikan karakter. Selain dapat dilihat pada nilai hasil belajar indikator dari hasil pengembangan nilai pendidikan karakter dapat dilihat dari prilaku para peserta didik yang selalu sopan dan santu dalam berkomunikasi serta taat dalam setiap aturan yang telah ditetapkan oleh pondok pesantren. ${ }^{15}$

Indikator dari pengembangan pendidikan karakter secara detil untuk tiap jenis nilai karakter sulit dioperasionalkan. Hal ini disebabkan tiap jenis nilai karakter tidak dapat berdiri sendiri, misalnya sikap jujur merupakan perwujudan dari nilai tanggung jawab dan nilai lain yang bersinergi. Demikian juga halnya dengan jenis-jenis nilai karakter yang lain. Indikator jenis-jenis nilai pendidikan karakter dari perspektif kepala sekalah dan guru tersebut dapat memberikan makna bahwa pendidikan karakter merupakan bagian integral dari pengembangan pendidikan di YP2QH Bagu.

Salah satu program pendidikan karakter yang berupa pembinaan bertujuan untuk meningkatkan kemampuan peserta didik dalam mengaktualisasikan potensi dirinya untuk mencapai tujuan pendidikan. Penyelenggaraan pendidikan harus diorientasikan kepada pemahaman nilai karakter sebagai tujuan penting pada setiap tingkatan pendidikan. Bentuk kegiatan itu dapat diberlakukan pada seluruh peserta didik, berupa

${ }^{15}$ Wawancara dengan TGH. Lalu. Moh. Turmudzi Badaruddin, 1-7 Agustus 2019. 
pembinaan keagamaan, mulai peningkatan pemahaman, penanaman sikap, sampai praktik dan aktualisasi dalam aktifitas keseharian.

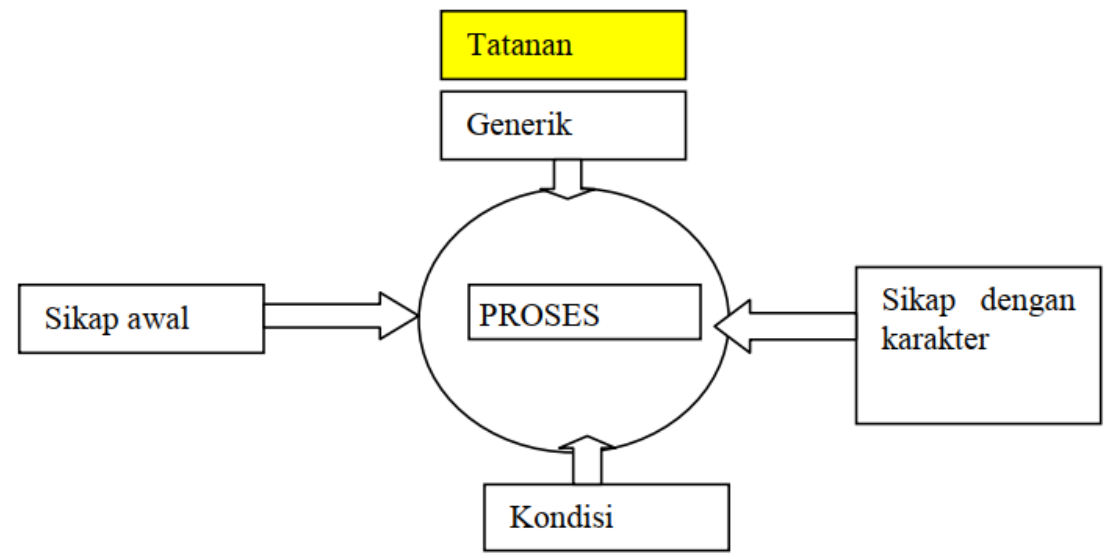

Lingkungan

Gambar 2. Peranan proses pendidikan dalam pembentukan karakter.

Sebagai suatu proses, pendidikan karakter dapat melahirkan asumsi-asumsi dalam pengembangannya. Pertama, pendidikan karakter diasumsikan sebagai sebuah proses yang terjadi secara tidak sengaja atau berjalan secara alamiah; dan kedua, pendidikan bisa dianggap sebagai proses yang terjadi secara sengaja, direncanakan, didesain, dan diorganisasi berdasarkan aturan-aturan. ${ }^{16}$ Oleh karena itu, pengembangan pendidikan karakter dapat dilakukan tidak saja pada lembaga pendidikan formal, tetapi juga pada lembaga pendidikan informal dan non-formal.

Nilai moralitas yang selalu ditekankan dalam ajaran-ajaran di pesantren adalah keikhlasan (al-Ikhlash), kemandirian (al-I'timad 'ala al-Nafs), kesederhanaan hidup (alIqtishad), asketis (al-Zubd), menjaga diri (al-Wara), dan lain-lain. Zamakhsyari Dhofir dalam disertasinya menulis mengenai tujuan pesantren sebagai berikut: Tujuan pendidikan tidak semata-mata untuk memperkaya pikiran santri dengan pelajaranpelajaran agama, tetapi untuk meninggikan moral, melatih dan mempertinggi semangat, menghargai nilai-nilai spiritual dan kemanusiaan, mengajarkan sikap dan tingkah-laku yang jujur dan bermoral, dan menyiapkan para santri untuk hidup sederhana dan bersih

16 Fatchul Muin, Pendidikan Karakter: Konstruksi Teoritik dan Praktik Urgensi Pendidikan Progresif dan Revitalisasi Peran Guru dan Orang Tua, hlm. 287. 
hati. Setiap santri diajarkan agar menerima etik agama di atas etik-etik yang lain. Tujuan pendidikan pesantren bukanlah untuk mengejar kepentingan kekuasaan, uang dan keagungan duniawi, tetapi ditanamkan kepada mereka bahwa belajar adalah semata-mata kewajiban dan pengabdian (ibadah) kepada Tuhan. ${ }^{17}$

Fungsi pendidikan dalam pembentukan karakter adalah transformasi kebudayaan dan nilai-nilai kepada peserta didik agar mampu memahami, menginternalisasikan dan menyampaikan kepada generasi berikutnya. ${ }^{18}$ Terdapat dua faktor pendidikan, yaitu faktor eksternal yang meliputi nilai dan kebudayaan, dan faktor internal berupa aktualisasi potensi-potensi yang dimiliki. Kedua faktor tersebut memiliki kekuatan yang sama dalam pembentukan karakter.

Pendidikan karakter seperti yang dijelaskan di atas memiliki peran dalam pembentukan sikap yang bernilai kemanusiaan. Dalam hal ini, penekanan pendidikan karakter berfokus pada apa dan bagaimana suatu sistem pendidikan dapat memiliki tatanan dan prosedur penanaman nilai karaketer yang berlandaskan pada norma yang diakui nilai kebenarannya, baik nilai-nilai moral dalam kehidupan bermasyarakat, bernegara dan nilai moral yang ada dalam Islam. Sistem pendidikan tersebut merupakan prasyarat utama bagi berkembangnya karakter dan kepribadian yang dibutuhkan pada setiap zaman.

\section{STRATEGI PENGEMBANGAN PENDIDIKAN KARAKTER DI PONDOK PESANTREN QOMARUL HUDA BAGU}

Kebijakan pendidikan karakter dapat ditemukan dalam beberapa regulasi yang telah diundangkan sebagai pijakan hukum (Gambar 3). Kebijakan pendidikan karakter menjadi dasar hukum dalam pengembangannya. Kebijakan tersebut berimplikasi pada semua lembaga pendidikan untuk melaksanakan pendidikan karakter. Landasan operasional dari aspek hukum bertujuan agar setiap lembaga pendidikan tidak ragu-ragu dalam mengembangkan pendidikan karakter sesuai dengan kurikulum pada tiap jenjang pendidikan.

\footnotetext{
${ }^{17}$ M. Zainul Fadli dan Erna Sulistyowati, "Peran Pesantren Mahasiswa dalam Membentuk Karakter Dokter Muslim," Jurnal Kesehatan Islam, Volume 1, 1 (2013), hlm. 1-12.

18 Abdul Mujib, "Konsep Pendidikan Karakter Berbasis Psikologi Islam," Prosiding Seminar Nasional Psikologi Islam di Fakultas Psikologi Universitas Islam Negeri Syaraif Hidayatullah Jakarta, 2012, hlm. 1-10.
} 
UU RI No 17 tahun 2007 tentang RPJPN

UU RI No 20 Tahun 2003 tentang sistem pendidikan nasional

Intruksi Presiden RI No 1 thaun 2010 tentang percepatan pelaksanaan prioritas pembangunan nasional tahun 2010

Rujukan penyusunan kebijakan nasional pendidikan karakter

Arahan Presiden RI pada sidang Kabinet terbatas bidang kesra tanggal 18 Maret 2010

Arahan Presiden RI pada rapat kerja nasional di Tampak Siring Bali tanggal 19-20 April 2010

Arahan Presiden RI pada Puncak Peringatan Hari Pendidikan Nasional di Istana Negara tanggal 11 Mei 2010

Gambar 3. Rujukan penyusunan kebijakan nasional pendidikan karakter. ${ }^{19}$

Strategi pengembangan pendidikan karakter dari perspektif pendidikan dapat meliputi beberapa tahapan penting, diantaranya adalah: (a) dimensi tahu, (b) dimensi bisa, (c) dimensi mau, dan (d) dimensi ikhlas. ${ }^{20}$ Aspek-aspek yang disebutkan merupakan substansi yang harus dikembangan dalam strategi dan metode pembelajaran pendidikan karakter. Selain substansi tersebut, strategi dan metode pengembangan pendidikan karakter mencakup hal-hal yang berkaitan dengan etika. Hal ini dapat dijelaslan sebagai berikut: (a) etika Islam menetapkan bahwa yang menjadi sumber moral, ukuran baik buruknya perbuatan didasarkan pada Alquran dan Sunnah, (b) etika Islam bersifat komprehensif, dan (c) etika Islam mengatur dan mengarahkan fitrah manusia kepada akhlak yang luhur. ${ }^{21}$

Pengembangan pendidikan karaketr pada YP2QH Bagu sebagai lembaga pendidikan formal berpedoman pada kurikulum nasional. Namun demikian, nilai-nilai Islam yang bernuansa religius yang menjadi ciri pesantren tetap menjadi dasar

\footnotetext{
${ }^{19}$ Ibid.

20Prayitno dan Belferik Manulang, Pendidikan Karakter dalam Pembangunan Bangsa (Jakarta: Grasindo, 2011), hlm. 85-86.

${ }^{21}$ Dian Andayani dan Abdul Majid, Pendidikan Karakter Perspektif, hlm. 14-15.
} 
pengembangan pendidikan karakter. Oleh karena itu, strategi pengembangan pendidikan karakter dapat berumber dari kurikulum nasional dan nilai-nilai dasar yang menjadi basis perjuangan pondok pesantren. Berkaitan dengan hal tersebut, peneliti melakukan wawancara mendalam dan diskusi dengan para kepala madrasah, guru dan pengasuh pondok, yaitu: (1) H. Mahyudin, S.Pd. M.Pd.I, Kepala MTs, (2) H. Zarkasi Efendi, S.Pd. M.Pd.I, Kepala MA, (3) H. Lalu Barsya, Kepala MI, (4) H. Muh. Tamin, Lc. (guru dan pengasuh pondok), dan (5) H. Moh. Yunus S.Pd.I. (guru dan pengasuh pondok). Kepala madrasah dan guru pada YP2QH Bagu menyatakan :

Strategi pengembangan pendidikan karakter dilakukan melalui dua pendekatan, yaitu integratif dan monolitik. Strategi integratif dilakukan pada mata pelajaran yang tidak secara khusus mengajarkan pendidikan karakter, dan strategi monolitik dilakukan pada mata pelajaran yang secara khusus mengajarkan tentang pendidikan karakter. Kedua strategi tersebut dipertahankan dan cukup efektif dalam pembentukan karakter peserta didik. Pendekatan integratif didasarkan oleh pandangan bahwa satu ilmu pengetahuan tidak dapat berdiri sendiri, tetapi saling melengkapi antara satu dan yang lain. Namun demikian, tiap bidang ilmu memiliki fokus sendiri-sendiri termasuk bidang ilmu yang memiliki relevansi dengan pendidikan karakter. ${ }^{22}$

Strategi pengembangan pendidikan karakter di atas menjelaskan model pendidikan di YP2QH Bagu. Selain berkaitan dengan strategi, para pengelola dan guru memiliki pemahaman yang memadai tentang jenis-jenis nilai karakter yang dikembangkan sebagai substansi dalam pembelajaran. Jenis-jenis nilai karakter yang dikembangkan adalah jenis nilai yang terakumulasi dalam akhlak mulia yang dicontohkan oleh Nabi Muhammad saw. Dalam pengembangan tiap jenis nilai karakter parameternya adalah seperti yang telah dirumuskan dalam tujuan baik itu tujuan yang ada dalam kurikulum, silabus dan rencana pembelajaran. Pengembangan nilai-nilai karakter pada YP2QH Bagu bertujuan agar para peserta didik memahami bahwa: (1) nilai karakter yang dipelajari bersumber dari nilai Islam yaitu Alquran dan Hadist, (2) nilai-nilai karakter yang dikembangkan adalah merupakan akhlak mulia Nabi Muhammad, (3) nilainilai karakter yang dipelajari dapat menghasilkan kepribadian yang luhur dan arif, dan (4) nilai-nilai karakter tersebut menjadi nilai dasar dalam pendirian pondok pesantren sebagai tempat menimba ilmu. ${ }^{23}$

\footnotetext{
${ }^{22}$ Wawancara dengan Kepala Madrasah dan Guru YP2QH, 1-7 Agustus 2019.

${ }^{23}$ Wawancara dengan Kepala Madrasah dan Guru YP2QH, 1-7 Agustus 2019.
} 
Keutamaan jenis-jenis nilai karakter dari perspketif pengelola dan guru di atas dapat menjelaskan tentang komitmen YP2QH Bagu dalam mengembangkan pendidikan karakter. Strategi pengembangan pendidikan karakter tersebut tidak dapat dilepaskan dengan metode. Mengenai metode pembelajaran, dinyatakan:

Strategi pengembangan nilai pendidikan karakter (akhlak) dari perspektif pengelola dan guru adalah sebagai berikut: (1) secara terstruktur substansi ada dalam matapelajaran yang memiliki relevansi dengan pendidikan karakter (akhlak), sehingga metode pembelajran sesuai dengan metode yang telah ditetpkan dalam rencana pembelajaran, (2) kegiatan ekstrakurikuler, pada kegiatan ini ditanamkan nilai yang berkaitan dengan tanggung jawab, kejujuran, disiplin serta kerjasama untuk mencapai tujuan (3) secara non formal dilakukan melalui kegiatan rutin pondok seperti shlat berjama'ah serta mengaji bersama sesuai dengan jadwal yang telah ditetpkan, (4) keteladanan, aspek ini ditanamkan pada semua guru dan pengelola agar memberikan keteladanan sesuai dengan nilai-nilai Islam yang ada pada Alquran dan hadist, (5) keteladan santri senior pada santri yunior. ${ }^{24}$

Strategi dan metode yang disebutkan di atas menjelaskan tentang praktek pengembagan pendidikan karakter pada YP2QH Bagu. Strategi dan metode pengembangan pendidikan karakter digunakan untuk memberikan pemahaman dan kompetensi peserta didik atau santri yang sesuai dengan standar yang ada dalam kurikulum, silabus dan rencana pembelajaran. Berkaitan dengan hal tersebut peneliti melakukan wawancara dan diskusi dengan beberapa santri Madrasah Aliyah dan Madrasah Tsanawiyah. Mereka mengungkapkan:

Nilai-nilai pendidikan karakter yang telah diterima selama berada pada pondok pesantren memiliki makna yang cukup penting karena mungkin tampa saya ikut belajar di pondok YP2QH Bagu tidak mengetahui apa yang sebenarnya dimaksudkan dengan karakter atau akhlak dalam kehidupan manusiai. Beberapa jenis nilai karakter saya maksudkan adalah jujur, adab (terhadap Allah, guru, orang tua, teman-teman dan lainlain), ikhlas, sabar, istiqomah dan betanggung jawab. Nilai-nilai tersebut telah mampu memberikan motivasi, sehingga dirasa waktu yang ada sangat terbatas untuk dapat menguasai semua ilmu yang diberikan oleh Tuan Guru, guru serta ustadz. ${ }^{25}$

Tuan Guru sebagai pemimpin pada YP2QH Bagu menggunakan strategi untuk mengembangkan pendidikan karakter, yaitu strategi umum dan strategi khusus. Sebagai pemimpin dan guru serta tokoh sentral dalam pondok pesantren memiliki strategi pengembangan pendidikan karakter yang disebut sebagai strategi umum. Strategi umum

\footnotetext{
${ }^{24}$ Wawancara dengan Kepala Madrasah dan Guru YP2QH, 1-7 Agustus 2019.

${ }^{25}$ Wawancara dengan Santri Madrasah YP2QH, 1-7 Agustus 2019.
} 
bukan hanya berkaitan dengan pembinaan santri, tetapi juga berhubungan dengan pembinaan jama'ah di luar santri. Strategi ini bertujuan agar jenis-jenis nilai pendidikan karakter tidak hanya dapat dipahami sebagai pengetahuan, tetapi untuk dipahami sebagai nilai utama yang dibutuhkan dalam kehidupan, khususnya bagi YP2QH Bagu.

Strategi umum dalam pengembangan pendidikan karakter memiliki kekuatan secara eksternal dalam mengembangkan pendidikan karakter. Tuan Guru memiliki kepedulian yang cukup tinggi. Hal ini dapat dilihat dari jadwal Tuan Guru dalam aktifitasnya seperti data yang diungkap pada Tabel di bawah ini:

Tabel .1. Jadwal Tuan Guru Bagu dalam Memberikan Tausiah pada Santri dan Alumni

\begin{tabular}{|l|l|l|l|l|}
\hline No & Jenis kegiatan & Tempat & Waktu & Keterangan \\
\hline 1 & Khatomul Qur'an & $\begin{array}{l}\text { Masjid Pondok } \\
\text { pesantren }\end{array}$ & $\begin{array}{l}\text { Setiap malam } \\
\text { jum'at }\end{array}$ & Peserta \pm 300 santri \\
\hline 2 & $\begin{array}{l}\text { Pengajian } \\
\text { Khusus }\end{array}$ & $\begin{array}{l}\text { Masjid Pondok } \\
\text { pesantren }\end{array}$ & $\begin{array}{l}\text { Setiap Hari } \\
\text { minggu }\end{array}$ & $\begin{array}{l}\text { Masyayikh } \pm \quad 100 \\
\text { Orang }\end{array}$ \\
\hline 3 & Pengajian khusus & $\begin{array}{l}\text { Masjidi Pondok } \\
\text { pesantren }\end{array}$ & $\begin{array}{l}\text { Setelah shalat } \\
\text { Magrib }\end{array}$ & Santriwati \\
\hline 4 & Pengajian khusus & $\begin{array}{l}\text { Masjid Pondok } \\
\text { pesantren }\end{array}$ & $\begin{array}{l}\text { Setelah shalat } \\
\text { Isya' }\end{array}$ & Santri \\
Subuh shalat & Ma'had Aly \\
\hline 5 & Pengajian khusus & $\begin{array}{l}\text { Masjid Pondok } \\
\text { pesantren }\end{array}$ & $\begin{array}{l}\text { Tahun ajaran } \\
\text { Baru }\end{array}$ & Santri baru \\
\hline 6 & Pengajian umum & $\begin{array}{l}\text { Luar pondok } \\
\text { pesantren }\end{array}$ & $\begin{array}{l}\text { Hari Besa } \\
\text { Islam }\end{array}$ & Masyarakat \\
\hline 7 & Pengajian umum & $\begin{array}{l}\text { Luar pondok } \\
\text { pesantren }\end{array}$ & $\begin{array}{l}\text { Tergantung } \\
\text { Jadwal }\end{array}$ & Masyarakat \\
\hline 8 & Haul Pasjid Pondok & $\begin{array}{l}\text { Tanggal } \\
\text { pendiria } \\
\text { pesantren } \\
\text { pondok } \\
\text { pesantren }\end{array}$ & $\begin{array}{l}\text { Masyarakat, alumni } \\
\text { dan santri }\end{array}$ \\
\hline
\end{tabular}

Data tersebut menunjukkan bahwa pendidikan karakter (akhlak) memiliki tempat tersendiri dalam proses pendidikan santri di pondok pesantren. Data tersebut dapat menjadi indikator dalam membedakan proses pembentukan nilai karakter pada pondok pesantren dan sekolah umum. Dalam hal ini, karakteristik pendidikan 
karakter di pondok pesantren tidak saja bertumpu pada kurikulum formal seperti yang distandarkan secara nasional, tetapi mengembangkan nilai-nilai karakter yang menjadi ciri khas pondok pesantren yang diintegrasikan dalam nilai-nilai karakter yang ada dalam kurikulum.

Karakter yang merupakan sifat individu seseorang dan melekat sebagai identitas cenderung menjadi dasar dari prilaku sesuai dengan norma yang diyakini sebagai ukuran dalam melakukan interaksi dan berkomunikasi dalam memenuhi kebutuhan hidup, baik yang bersifat rohani maupun jasmani. Dalam situasi sosial masyarakat yang penuh dengan dinamika dewasa ini, pendidikan karakter perlu diimplemtasikan pada semua jenjang pendidikan dalam rangka menumbuhkan rasa sosial yang tinggi, membangkitkan emosi positif, menumbuhkan rasa kepekaan terhadap sesama, dan mewujudkan rasa tanggung jawab yang tinggi sehingga dapat menjadi pribadi yang utuh dan berakhlak mulia. ${ }^{26}$ Oleh karena itu, pengembangan pendidikan karakter membutuhkan strategi sebagai cara untuk mencapai tujuan. Strategi pengembangan pendidikan karakter dapat dijelaskan sebagai berikut:

Strategi pendidikan karakter dapat meliputi materi dan kompetensi yang mengacu pada standar yang sudah ditetapkan dalam kurikulum dan proses pembelajarannya dan dapat dilakukan melalui empat model pembelajaran: (1) model otonomi dengan menempatkan pendidikan karakter sebagai mata pelajaran sendiri, (2) model integrasi dengan menyatukan nilai-nilai dan karakter yang akan dibentuk dalam setiap mata pelajaran, (3) model ekstrakurikuler melalui sebuah kegiatan tambahan yang berorientasi pembinaan karakter siswa, (4) model kolaborasi dengan menggabungkan ketiga model tersebut dalam kegiatan sekolah. ${ }^{27}$

\section{KESIMPULAN}

1. Pengembangan pendidikan karaketr pada YP2QH Bagu sebagai lembaga pendidikan formal berpedoman pada kurikulum nasional. Namun demikian, nilai-nilai Islam yang bernuansa religius yang menjadi ciri pesantren tetap menjadi dasar pengembangan pendidikan karakter. Strategi pengembangan pendidikan karakter dilakukan melalui dua pendekatan, yaitu integratif dan monolitik. Strategi integratif dilakukan pada mata pelajaran yang tidak secara khusus mengajarkan pendidikan karakter, dan strategi monolitik dilakukan pada mata pelajaran yang secara khusus

26Prayitno dan Belferik Manulang, Pendidikan Karakter dalam Pembangunan Bangsa, hlm. 47.

${ }^{27}$ Barnawi dan M. Arifin, Strategi dan Kebijakan Pembelajaran Pendidikan Karakter, hlm. 65-68. 
mengajarkan tentang pendidikan karakter. Kedua strategi tersebut dipertahankan dan cukup efektif dalam pembentukan karakter peserta didik.

2. Deskripsi tentang sumber nilai dapat memberikan makna dalam proses pengembangan pendidikan karakter sebagai berikut: (1) sumber nilai karakter yang ada pada YP2QH Bagu adalah sumber yang memiliki nilai yang tinggi, (2) sumber nilai pengembangan pendidikan karakter memiliki relevansi dan selalu sesuai dengan setiap jaman, dan (3) sumber nilai pengembangan pendidikan karakter bersifat universal.

3. Jenis-jenis nilai karakter sebagai sumber moral menjelaskan tentang tata nilai atau norma kehidupan di YP2QH Bagu. Dalam hal ini dapat dipahami bahwa pendidikan di YP2QH Bagu adalah pendidikan dengan indikator dari out-put dengan ciri memiliki integritas dan tanggungjawab yang tinggi, baik dalam berhubungan secara vertikal dengan Allah dan secara horizontal baik sebagai individu maupun sebagai anggota masyarakat. Nilainilai adab berhubungan dengan Allah, seperti iman, taqwa, taubat, khauf, zuhud, syukur, ikhlas dan tawakal. Nilai adab berhubungan dengan sesama manusia adalah adab pergaulan, keteladanan, tolong monolong, kasih sayang, jujur dan kebersamaan. Nilai-nilai adab terhadap alam menjunjung tinggi kebenaran, berkorban, patuh pada hukum, kerja keras dan peduli terhadap lingkungan alam sekitar.

4. Pandangan empiris Tuan Guru sebagai pemimpin pada YP2QH Bagu dalam pengembangan pendidikan karakter dapat dirumuskan sebagai berikut: (1) melanjutkan dan mewariskan jenis-jenis nilai karakter yang diperoleh dari para ulama tempat Tuan Guru menimba ilmu, (2) tuntutan masyarakat dalam menghadapi perubahan global yang telah mengikis nilainilai karakter dalam kehidupan masyarakat. Hal ini menjelaskan bahwa pesantren sebagai lembaga pendidikan memiliki tradisi yang kuat dalam mengembangkan pendidikan karakter. Tradisi pondok pesantren seperti inilah yang membedakannya dari lembaga pendidikan yang lain. 


\section{DAFTAR PUSTAKA}

Abdul Mujib, "Konsep Pendidikan Karakter Berbasis Psikologi Islam," Prosiding Seminar Nasional Psikologi Islam di Fakultas Psikologi Universitas Islam Negeri Syaraif Hidayatullah Jakarta, 2012

Akhmad Muthohar AR, Ideologi Pendidikan Pesantren: Pesantren di Tengah Arus IdeologiIdeologi Pendidikan (Pustaka Rizki Putra, 2007)

Barnawi dan M. Arifin, Strategi dan Kebijakan Pembelajaran Pendidikan Karakter (Yogyakarta: Ar-Ruzz Media, 2012)

Departemen Agama RI, Direktorat Jenderal Kelembagaan Agama Islam, Direktorat Pendidikan Keagamaan dan Pondok Pesantren, Petunjuk Teknis Pondok Pesantren (Jakarta: Departemen Agama RI, 2003)

Dian Andayani dan Abdul Majid, Pendidikan Karakter Prespektif Islam (Bandung: Remaja Rosda Karya, 2011)

Direktorat Pendidikan Diniah dan Pondok Pesantren, Direktorat Jenderal Pendidikan Islam Departemen Agama RI, Pedoman Pengembangan Kurikulum Pesantren (Jakarta: Direktorat Pendidikan Diniah dan Pondok Pesantren, 2009)

Faiqoh, Prospek dan Problem Pesanteren di Era Modern (Gaung Persada Press, 2013)

H. E. Mulyasa, Manajemen Pendidikan Karakter (Jakarta: Bumi Aksara, 2011)

Herry Widyastono, "Penyelenggaraan Pendidikan Karakter Melalui Optimalisasai Pelaksanaan Kurikulum Tingkat Satuan Pendidikan," Jurnal Pendidikan dan Kebudayaan,Vol.6 (2010)

Kamil Sumardi, "Potret Pendidikan Karakter di Pondok Pesantren Salafiah," Jurnal Pendidikan Karakter, Vol.2, 3 (2012)

Kementerian Koordinator Kesejahteraan Rakyat Republik Indonesia, Kebijakan Nasional Pembangunan Karakter Bangsa (Jakarta: Kemenko Kesra, 2010)

M. Tholhah Hasan, Intelektualisme Pesantren: Potret Tokoh dan Cakrawala Pemikiran di Era Perkembangan Pesantren (Diva Pustaka, 2004)

M. Zainul Fadli dan Erna Sulistyowati, "Peran Pesantren Mahasiswa dalam Membentuk Karakter Dokter Muslim,” Jurnal Kesehatan Islam, Volume 1, 1 (2013)

Nurcholish Madjid, Bilik-Bilik Pesantren (Jakarta: Dian Rakyat, 2009)

Nuria Isna Aunnilah, Panduan Menerapkan Pendidikan Karakter di Sekolah (Laksana, 2011)

Prayitno dan Belferik Manulang, Pendidikan Karakter dalam Pembangunan Bangsa (Jakarta: Grasindo, 2011)

Sa'dun Akbar, "Revitalisasi Pendidikan Karakter di Sekolah Dasar," Pidato Pengukuhan Guru Besar Dalam Bidang Ilmu Pendidikan/Pendidikan Dasar, Universitas Malang Tanggal 8 Juni 2011

Sri Wahyuni Tanshzil, "Model Pembinaan Pendidikan Karakter pada Lingkungan Pondok Pesantren dalam Membangun Kemandirian dan Disiplin Santri," Jurnal Penelitian Pendidikan, Vol. 13, 2 (2012)

Zaim Elmubarok, Membumikan Pendidikan Nilai (Bandung: Alfabeta 2008) 